\title{
Low Fertility in Canada: The Nordic Model in Quebec and the U.S. Model in Alberta
}

\author{
Roderic Beaujot \\ Population Studies Centre \\ Department of Sociology \\ University of Western Ontario \\ London, Ontario, Canada \\ E-mail: rbeaujot@uwo.ca \\ Juyan Wang \\ Population Studies Centre \\ Department of Sociology \\ University of Western Ontario \\ London, Ontario, Canada
}

\begin{abstract}
Among the factors that are responsible for low fertility, the risks experienced by young people are particularly relevant. In that context, it is noteworthy that fertility is rising most in Alberta and Quebec, that is in provinces where young families have had the security of either good job opportunities or supportive social policy. The fertility trend in Canada has seen a low point of 1.51 in 2002, rising to a total fertility rate of 1.66 in 2007. The trends and differences are placed in the context of family and work questions, including the division of paid and unpaid work by gender. By marital status, family structure and work orientation, fertility is highest for women and men who are married, with no step children and intermediate work orientation. We summarize the changing policy context, proposing that social policy has become more supportive of families with young children, especially in Quebec but also in the rest of Canada.
\end{abstract}

Key Words: Low fertility, Alberta, Quebec 


\section{Résumé}

Parmi les facteurs responsables du faible taux de fécondité, les risques que subissent les jeunes sont spécialement pertinents. Dans ce contexte, il est important de noter que le taux de fécondité est le plus en hausse en Alberta et au Québec; ce qui veut dire dans des provinces où les jeunes familles on bénéficiées de la sécurité qu'apporte de bonnes opportunités d'emploi ou une bonne police de soutien social. Les tendances de fécondité au Canada ont atteint leur plus bas point à 1.51 en 2002, pour ensuite remonter à un taux de fécondité de 1.66 en 2007. Les tendances et les différences sont placées dans le contexte de questions familiales et d'emploi qui comprennent la division de travail rémunéré et nonrémunéré par sexe. Analysé par statut matrimonial, structure familiale et orientation au travail, le taux de fécondité est plus haut pour les femmes et les hommes qui sont mariés, sans beaux-enfants et avec une orientation au travail intermédiaire. Nous résumons le contexte changeant des polices et avançons que la police sociale soutient de plus en plus les familles de jeunes enfants, particulièrement au Québec mais aussi dans le reste du Canada.

Mots-clés: Faible taux de fécondité, Alberta, et Québec

\section{Introduction}

Canadian fertility has increased over the last five years, from 1.51 in 2002 to 1.66 in 2007. The increases have been highest in Quebec and Alberta. In Quebec, the increase has been occurring over the period 2000 to 2007 , from a total fertility rate of 1.45 to 1.65 (Institut de la statistique du Québec 2008: 28). In Alberta, the increase is from 1.64 in 2000 to 1.90 in 2007 (Statistics Canada 2009: 21).

While many considerations are at stake in low fertility, it would appear that questions of economic risks and policy support are key matters (McDonald 2006; Gauthier and Philipov 2008). Roy and Bernier (2006) had argued that the Quebec family and policy trends were coming to resemble the Nordic model, with a high proportion of births in cohabiting unions, and considerable state support, especially through the Ministère de la Famille, des Aînés et de la Condition féminine. 
But the United States has managed higher fertility through a model that involves low state support. There are clearly are various factors underlying the higher fertility in United States, including the higher levels of certain minority groups (Bélanger and Ouellet 2002). In addition, the strong job growth experienced in the United States after the recession of the early 1990 s has meant that, even with poor job protection, withdrawals from the labour force were less risky; people could be confident of their employment prospects when they desired to return to the labour market. In Canada, the most recent period has seen Alberta emerge as the province of strong job growth, to the point that in some years it was the only province with a substantial positive net internal migration. Commenting on the labour force data for 2006, The Globe and Mail used the headline: "Women in the East join work force, women in West leave in droves" (Scoffield 2006). Exaggerated as the headline was, it may have touched a reality in terms of alternative opportunities and preferences during this period of resource-sector growth in Alberta.

While it was a rather different context, the baby boom also occurred in a period of "golden years of secure employment and the social welfare state" as "the most risk-free period in history" (Caldwell 2005). For men in the 1940s and 1950s, what counted for having children was to be a married breadwinner. In contrast, Lauster (2008) finds that since the 1970 s, it is when they are home owners that men are properly established to have children.

There is much heterogeneity both in fertility preferences and in the fertility constraints that people experience. A central aspect of this heterogeneity is the gender models for the division of earning and caring activities (Beaujot 2000). This also means that a variety of policies are relevant, to support people in various family/work models.

After looking more closely at the fertility trend in Canada, this paper considers questions of fertility and work, along with the division of paid and unpaid work by gender. We then consider actual and intended fertility following on marital and work status of women and men. Finally, we summarize the changing policy context, proposing that social policy has become more supportive of families with young children, especially in Quebec but also in the rest of Canada. 


\section{The Fertility Trend and the Second Demographic Transition}

Following on the stages of the second demographic transition as proposed by Lesthaeghe (1995), the first stage was from about 1960 to 1970 , with the end of the baby boom, the end of the trend toward younger ages at marriage, and the beginning of the rise in divorces (Table 1). The second stage, from 1970 to 1985 , included the growth of common-law unions and eventually of children in cohabiting unions. The third stage, since 1985 shows a plateau in divorce, an increase in postmarital cohabitation, and a plateau in fertility due in part to higher proportions of births after age 30. For 1981-2007, the total fertility rate has been in the range of 1.5 to 1.7 births per woman. On an annul basis, there is a peak of 1.71 in 1990, then a trough of 1.51 in 2002, and an increase to 1.66 in 2007 (Statistics Canada 2008: 8, 33; Statistics Canada 2009: 21).

The current phase of the demographic transition especially involves tempo changes to later ages for union formation and childbearing. Age 30 is a key point in the graphs showing fertility rates at given ages for successive cohorts (Figure 1). In particular, the reduced levels before age 30 are partly compensated with higher levels after age 30. In effect, the slight increases in total fertility in the period 2002-2007 are a function of the increases at ages 30-39 being larger than the decreases at ages 20-29. Further data by parity for Quebec show increases at ages 26-29 in the period since 2001, along with the increases at ages 30+ which have occurred over the period 1986-2006 (Institut de la statistique du Quebec 2008: 29-32). These Quebec data show increases at each of the three first birth orders, even though the average age at each parity continues to increase. Compared to earlier cohorts, these Quebec data show increases in total births to age 40 as of the 196162 birth cohort, and as of age 50 for cohorts since the one of 1957-58. Consequently, completed fertility as of age 50, which had declined to 1.61 for the 1954-58 cohorts in Quebec, is estimated to rise to 1.72 for the 1972-73 cohort. For Canada as a whole, cohort fertility declined from 3.4 in the birth cohorts of the late 1920 s, to 1.8 in the cohorts of the early $1950 \mathrm{~s}$, but it has been estimated in the stable range of 1.74 to 1.76 for cohorts from the mid 1960s to the late 1970s (Statistics Canada 2008: 33).

The assumptions used in population projections are another useful indicator of trends. The medium fertility assumptions have been set at 1.7 after the censuses of 1981, 1986 and 1991, and at 1.5 after the 1996 and 2001 censuses. Over this period, the high assumptions have declined from 2.2 to 1.7 and the low assumptions have been in the range 
Table 1

Summary Statistics on Family Change and Fertility for Canada: 1941-2006

\begin{tabular}{|c|c|c|c|c|c|c|c|c|c|c|c|}
\hline Variables & 1941 & 1951 & 1961 & 1971 & 1976 & 1981 & 1986 & 1991 & 1996 & 2001 & 2006 \\
\hline Divorces per 100,000 & & & & & & & & & & & \\
\hline Married Couples & -- & 180 & 180 & 600 & 990 & 1129 & 1220 & 1110 & 1130 & 1100 & 1140 \\
\hline $\begin{array}{l}\text { Common-law Couples as a } \\
\text { Percent of all Couples }\end{array}$ & - & - & -- & - & 0.7 & 6.4 & 8.2 & 11.2 & 13.7 & 16.4 & 18.6 \\
\hline Lone-parent Families as a & & & & & & & & & & & \\
\hline $\begin{array}{l}\text { Percent of all Families } \\
\text { with Children }\end{array}$ & 9.8 & 9.8 & 11.4 & 13.2 & 14.0 & 16.6 & 18.8 & 20.0 & 22.3 & 24.7 & 25.8 \\
\hline $\begin{array}{l}\text { Births to Non-married Women } \\
\text { as a Percent of all Births }\end{array}$ & 4.0 & 3.8 & 4.5 & 9.0 & -- & 16.7 & 18.8 & 28.6 & 36.9 & 38.2 & 37.7 \\
\hline Median Age at First Marriage & & & & & & & & & & & \\
\hline Brides & 23.0 & 22.0 & 21.1 & 21.3 & 21.6 & 22.5 & 23.9 & 25.1 & 26.3 & 26.0 & $27.0^{*}$ \\
\hline Grooms & 26.3 & 24.8 & 24.0 & 23.5 & 23.7 & 24.6 & 25.8 & 27.0 & 28.3 & 27.0 & $29.0^{*}$ \\
\hline $\begin{array}{l}\text { Births to Women Aged 30+ } \\
\text { as a Percent of all Births }\end{array}$ & 35.6 & 36.2 & 34.1 & 21.6 & 19.6 & 23.6 & 29.2 & 36.0 & 43.7 & 46.9 & 48.9 \\
\hline Median Age at First Birth & 24.3 & 23.5 & 22.8 & 22.9 & 23.6 & 24.5 & 25.1 & 26.2 & 27.1 & 27.6 & 28.1 \\
\hline $\begin{array}{l}\text { Total Fertility Rate } \\
\text { (average births per women) }\end{array}$ & 2.8 & 3.5 & 3.8 & 2.1 & 1.8 & 1.7 & 1.6 & 1.7 & 1.6 & 1.5 & 1.6 \\
\hline
\end{tabular}

Notes: For 1941-71 births to non-married women are designated as illegitimate births.

Median age at first birth: mean age shown for 1986-96

*refers to 2003 data

Sources: Statistics Canada, no. 82-553, 1992: Tables 10, 16, 3; Statistics Canada, no. 82-552, 1992: Table 14;

Statistics Canada, no. 84-212, 1995; Statistics Canada, no. 91-209, 1996: 19; Statistics Canada, no. 84-204, 1971;

Statistics Canada, no.84-213,1991,1987-1988, 2003;

Special tabulations, Statistics Canada: CANSIM Table 102-4508, CANSIM, Statistics Canada.

Beaujot and Kerr, 2004: 212; 1941 Census, vol. V.: Table 19; 1951 Census, vol. III.: Table 136;

Statistics Canada, 84-210, 1996, 2001, 2004; Statistics Canada, 84-214, 1996; 


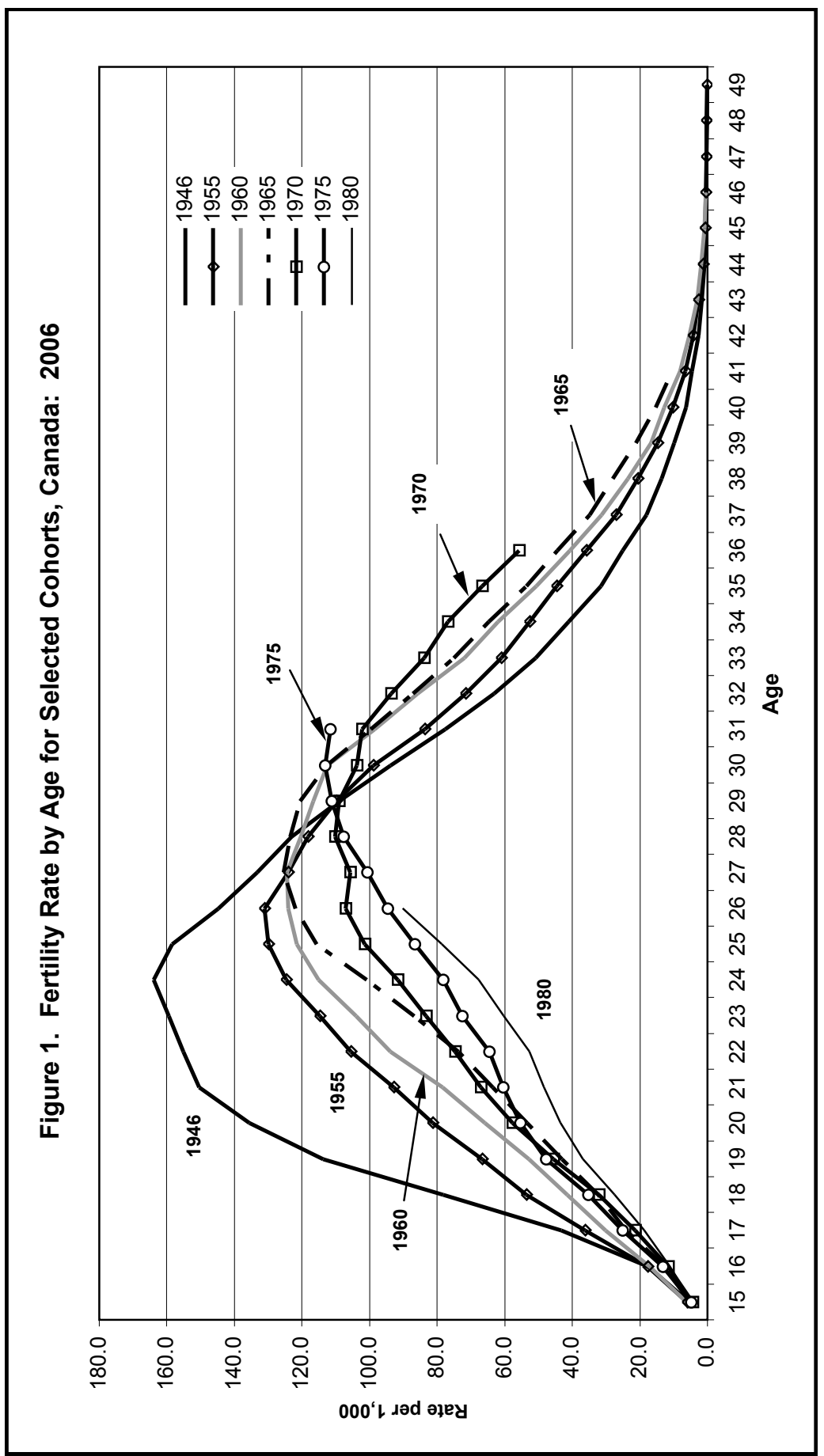

CSP 2010, 37.3-4: 411-443

416 
Low Fertility in Canada:

The Nordic Model in Quebec and the U.S. Model in Alberta

of 1.4 to 1.2 (Beaujot and Kerr 2004: 158). The projections for Quebec have followed a similar pattern. However, in anticipating the next round of projections, following the 2006 census, demographers at both Statistics Canada and Institut de la statistique du Québec are proposing to use slightly higher assumptions.

Canadian levels are similar to those of the average for the 27 European Union countries (Vienna Institute of Demography 2008). For instance, the total fertility rate in EU-27 was 1.53 in 2006 compared to 1.59 for Canada, and the completed fertility for the 1965 birth cohort is 1.79 in EU-27 compared to 1.75 for Canada. Similarly, the average age at first birth is 28.1 for Canada and 27.7 for EU-27. Goldstein et al. (2009) observe that in 2003 there were 21 countries in Europe and East Asia with total fertility rate below 1.3 , compared to five in 2008 , and that the upturn in fertility has affected most of the developed world. In terms of the progression of cohabitation, Quebec has more similarities to the Nordic countries, with 60 percent of births being to women who are not married, while the rest of Canada is more similar to the United States, where cohabitation is a form of conjugal life and a test of the relationship, more than an alternative form of family life (Le Bourdais and Lapierre-Adamcyk 2004; Kiernan 2001). While an increased proportion of births are to cohabiting unions, the proportion with no declared father on the birth certificate has declined to 2.7 percent of Quebec births in 2007 (Institut de la statistique du Québec 2008: 37).

\section{Work and Childbearing}

In the period 1960 to 1985 , the total fertility rate was declining as fast as women's employment rate was increasing (Figure 2). Less noticeable is that this inverse relationship between the two time-series does not apply for the whole post-war period. During the 1950s, both fertility and women's employment were increasing. Since 1985, fertility has been relatively stable while women's employment rate has continued to rise, other than for the period of the early 1990s.

Across countries, the inverse relation which was observed into the 1970s between rates of fertility and women's labour force participation, have become positive since the mid-1980s (Morgan 2003; Coleman 2005: 438; Never 2008; Billari 2008; Thévenon 2008). The same results are seen when Canadian provinces are used as the units of analysis (Figure 3). In particular, in 1976, there was basically no relationship between fertility rates and women's employment rates, while the relation became more and more positive until 1996, with positive but weaker relationships in 2001 and 2006. For men, the relationship between 


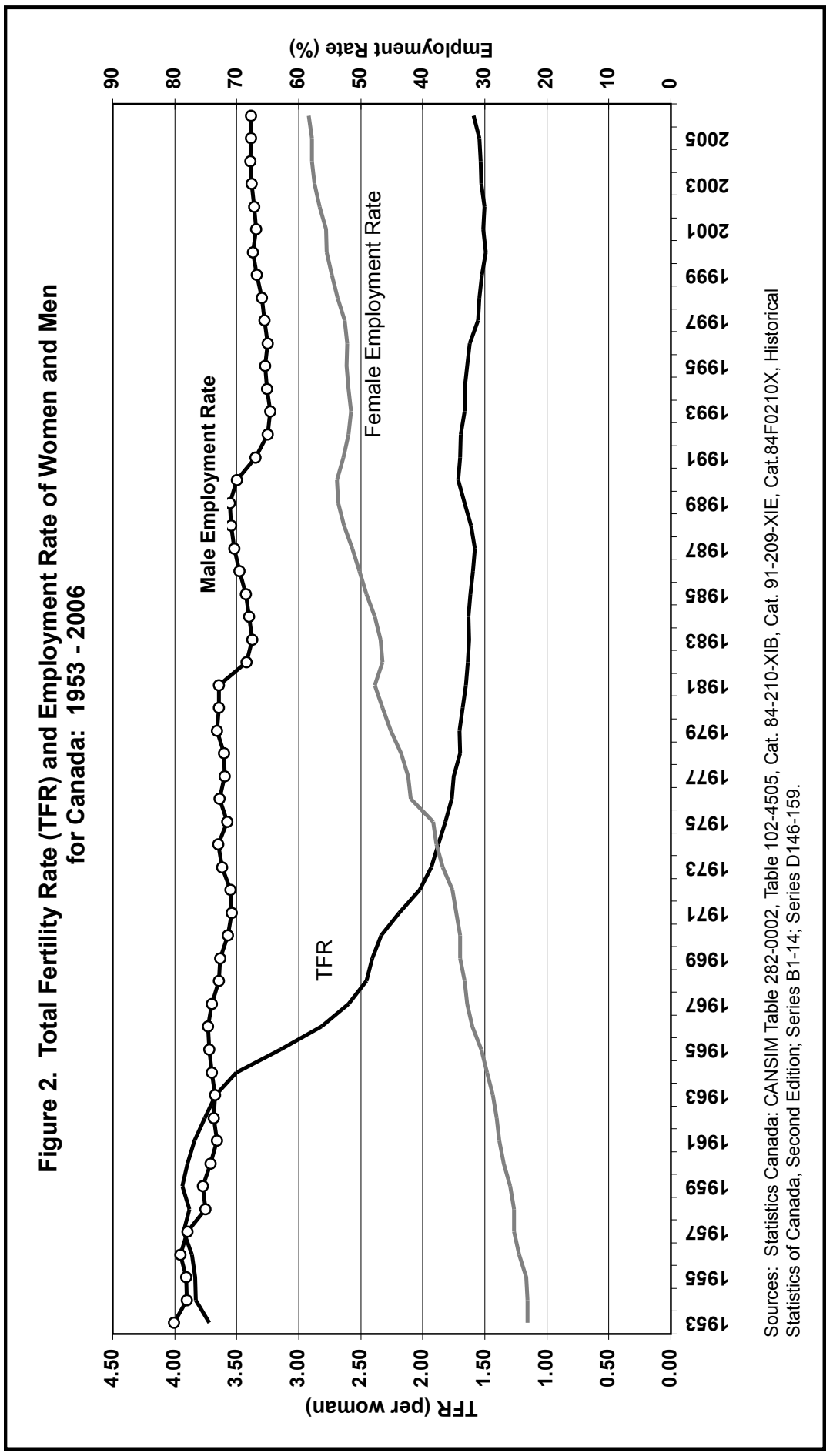

CSP 2010, 37.3-4: 411-443 418 

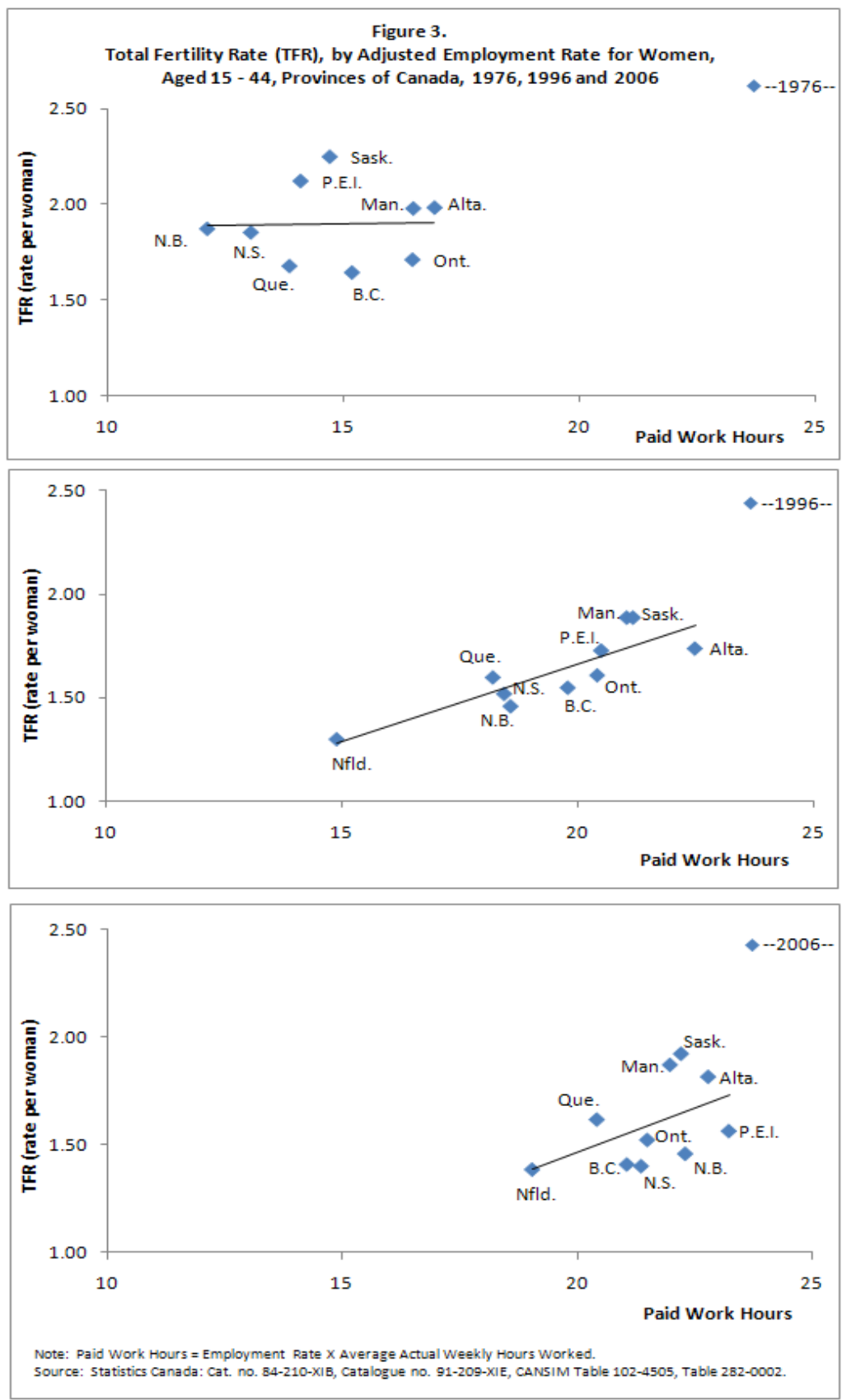

CSP 2010, 37.3-4: 411-443 
fertility and their employment rates have been positive since 1976, but the correlations increased to 1996, with slightly lower correlations for 2001 and 2006 (Table 2).

In 2006, the point for Quebec shows higher fertility than one would expect from the regression line on employment rate, as was also the case in 1996, but to a lesser extent. For Alberta, the 1996 fertility was lower than expected from women's employment rate, but the point for 2006 is now above the regression line. The pattern could be interpreted to mean that the mediating impact of Quebec's subsidized day care program has been stronger than the previous program of direct subsidies to families with young children.

Table 2

Pearson Correlation Coefficients between Employment Rate And Total Fertility Rate for Canada: 1976-2006

\begin{tabular}{lllll}
\hline Year & $\begin{array}{c}\text { Between Employment } \\
\text { Rate and TFR }\end{array}$ & $\begin{array}{c}\text { Between Adjusted } \\
\text { Employment Rate } \\
\text { and TFR }\end{array}$ \\
\hline $\mathbf{1 9 7 6}$ & 0.07 & 0.24 & 0.02 & 0.63 \\
$\mathbf{1 9 8 1}$ & 0.20 & 0.41 & 0.18 & 0.69 \\
$\mathbf{1 9 8 6}$ & 0.57 & 0.48 & 0.53 & 0.78 \\
$\mathbf{1 9 9 1}$ & 0.78 & 0.71 & 0.76 & 0.83 \\
$\mathbf{1 9 9 6}$ & 0.86 & 0.84 & 0.85 & 0.90 \\
$\mathbf{2 0 0 1}$ & 0.81 & 0.83 & 0.69 & 0.86 \\
$\mathbf{2 0 0 6}$ & 0.63 & 0.76 & 0.49 & 0.84 \\
\hline
\end{tabular}

Notes: Employment rate is for age group 15-49; Average weekly hours worked is for age group 15-44.

Adjusted Employment Rate = Employment Rate x Average Weekly Hours Worked.

Sources: Statistic Canada, CANSIM Table 282-0002, Table 282-0028, Table 102-4505; Cat. 84-210-XIB; Cat. 91-209-XIE. 
The level of childbearing needs to be placed within the opportunity structures of young persons as these evolve over time. As Wheeler (2008: 6) indicates, "babies tend to be born where the jobs are." Similarly, Roy and Bernier (2006) propose that employment continues to be the foundation of social and occupational integration, and weak job prospects, like the growth of non-standard work, are not incentives for having children. Bingoly-Liworo and Lapierre-Adamcyk (2006) find that the delay in first births are increasingly due to the longer period of education, and the difficulty of obtaining stable employment. First births are related to both stability in employment and the ability to rely on spouse's employment (Bingoly-Liworo 2007). This study also finds for the period 1996-2004 that women who did not work in the reference year are less likely to have a first child (idem, p. 157, 162). In France, Testa and Toulemon (2006) find that two jobs predicts the transition to first birth, as does being married or cohabiting.

Several commentators have observed that the prospects for young men have deteriorated since the mid 1970s, that is after the "leading edge" of the baby boom had entered the labour force (Morissette 1998; Kapsalis et al. 1999; Beaupré et al. 2006; Clark 2007). Since the mid1980 s, for workers under 35 , especially men, earnings have declined, educational premiums over older counterparts has disappeared, there is lower job quality, less pension coverage, lower unionization rates, increased earnings instability, increased wage gaps between newly hired and those with more experience, and lower likelihood that men under 35 have full-year full-time employment than in the 1970s. This is probably partly a question of the size of the baby boom, and partly a question of timing with slower economic and job growth since the mid 1970s.

It was thought that the "baby bust," born between 1967 and 1979, would have better prospects, since they were a smaller cohort (Foot, 1998). However, into the beginning of the $21^{\text {st }}$ century, these subsequent cohorts have been disadvantaged by following the large baby boom cohort. With a more competitive labour market, they have pursued more education, and the two-income model, partly as a means of achieving the desired standard of living. This has brought delays in early life transitions, including home leaving, union formation, and childbearing (Beaujot 2006; Clark 2007). Especially in the two-income model, the "career entry theory of marriage" is particularly applicable, including low marriage propensities during post-secondary education (Oppenheimer 1998; Sweeney 2002; Goldscheider et al. 2006).

There was concern in the late 1990s that labour force participation would stop increasing, after four decades of growth brought about especially through women's increasing participation (Sunter 2001). It was observed that men's participation rates were declining at ages over 
55 , and that rates were declining at ages 15-24 due especially to higher participation in education. The early part of the present century has seen increased participation, at least until the recession of 2008 (Cross 2006; Morissette and Johnson 2005). Chung (2006) finds that in 2000-05 average real earnings have increased at a faster pace for young, lesseducated male workers than for any other group. Based on data for 1997/1998 to 2006/2007, Morissette (2008) finds that men under 35 have made more gains than at ages 35-64.

Other indicators have shown important progress over the period 1981-2006, including the proportion of dwellings that are owneroccupied (Gauthier 2009: 6). The labour force projections made in 2006 anticipated increased age specific rates to 2011 for men and to 2021 for women (Martel et al. 2007; Beaujot et al. 2007). The employment rate reached a peak in March 2008, at 63.8 percent of the population aged 15+ employed, compared to 61.1 in 2001 and 52.2 in 1951. It would appear that recent labour market entry cohorts are sufficiently distant from the baby boom cohort that their opportunity prospects are less affected by the bulge in the age distribution. However, as mandatory retirement is being set aside, and the baby boom cohorts are concerned about their pension funds in declining equity markets, the much anticipated opportunities for younger cohorts are being postponed through the current recession. Already in 2008, there were employment gains at 55+ compared to declines at ages 15-24 (Usalcas 2009).

\section{Gender, Work and Childbearing: Alternate Models}

Another factor that has been shifting slowly in favour of childbearing is the greater participation of men in housework and child care. Reviewing trends in time-use over the period 1986 to 2005, Marshall (2006) uses the title "Converging gender roles." For instance, at ages 25-54, in 1986 men did an average of 43 percent of the amount of unpaid work as women, while in 2005 men did 58 percent of women's average hours per day (see Table 3). Among men aged 25-54 who were living as a couple with a child under 5 at home, 57 percent participated in primary child care in 1986, compared to 73 percent in 2005 . For persons with children under five, the time spent doing child care has increased for both men and women, but especially for men (Gauthier et al. 2004: 661). For persons who worked at least three hours on the observation day, the family time with spouse and/or children declined between 1986 and 2005, but the gender differences in this family time are very small (see Table 3 ).

For persons in couples where neither spouse is a full-time student nor retired, there has been a decrease in complementary-traditional 
arrangements, along with an increase in men's double burden arrangements and in shared roles arrangements (Beaujot et al. 2009). Surveys indicate an increasing preference for the sharing of housework and child care (Gil Alonso 2005; see also Beaujot 2007).

There are clearly two models of family and work that underlay childbearing. In one model, childbearing is more extensive for women who are in complementary role relationships or who are less attached to the labour force. In another model, once women have secure jobs and workplace support, they will be in position to realize their childbearing goals.

Comparisons across countries suggest that the structure of work is an important determinant of child-bearing. For instance, comparing the pro-natalist policies of France and Japan, Boling (2008) concludes that the difficulties in Japan relate to the labour market which "extracts high opportunity costs from parents who interrupt their careers to raise children, keeps ideal workers from having much time for their families, assumes and reinforces a traditional gender ideology, and hires few young workers into good jobs." Similarly, McDaniel (2008) places part of the responsibility for Korea's low fertility on the increased insecurity in the labour market. A comparison of Germany and France indicates that women without children have higher labour force participation in Germany, but when women have one or more children it is in France where they have higher participation (Pailhé 2008). The potential for flexibility of given occupations is another structural factor. For instance, using Canadian data, Ranson (1998) finds that women in the education and health sectors had more supports for childbearing than women in law or business. The earnings of women with children are especially affected by having taken more time off from work than women without children (Zhang 2009).

Another structural feature is the extent of sharing of family work. McDonald (2000) has theorized that fertility is particularly low when women have attained equal opportunities in education and work, but families have remained traditional, allocating an excessive component of reproductive work to women. Bernhardt (2005) proposes that this low fertility is because only the first half of the gender revolution has been completed; the second half of the gender revolution, in the private sphere, remains incomplete. There is some evidence of higher fertility when men share more of the household burdens (Pinnelli 2001; Gil Alonso 2005; Purr et al. 2009). Research from Sweden shows that wives are more likely to have a second child if their husbands had taken parental leave for a previous birth (Olah 2003). The comparison of fertility trends in Spain and Denmark shows that only in Denmark does the relatively equal 


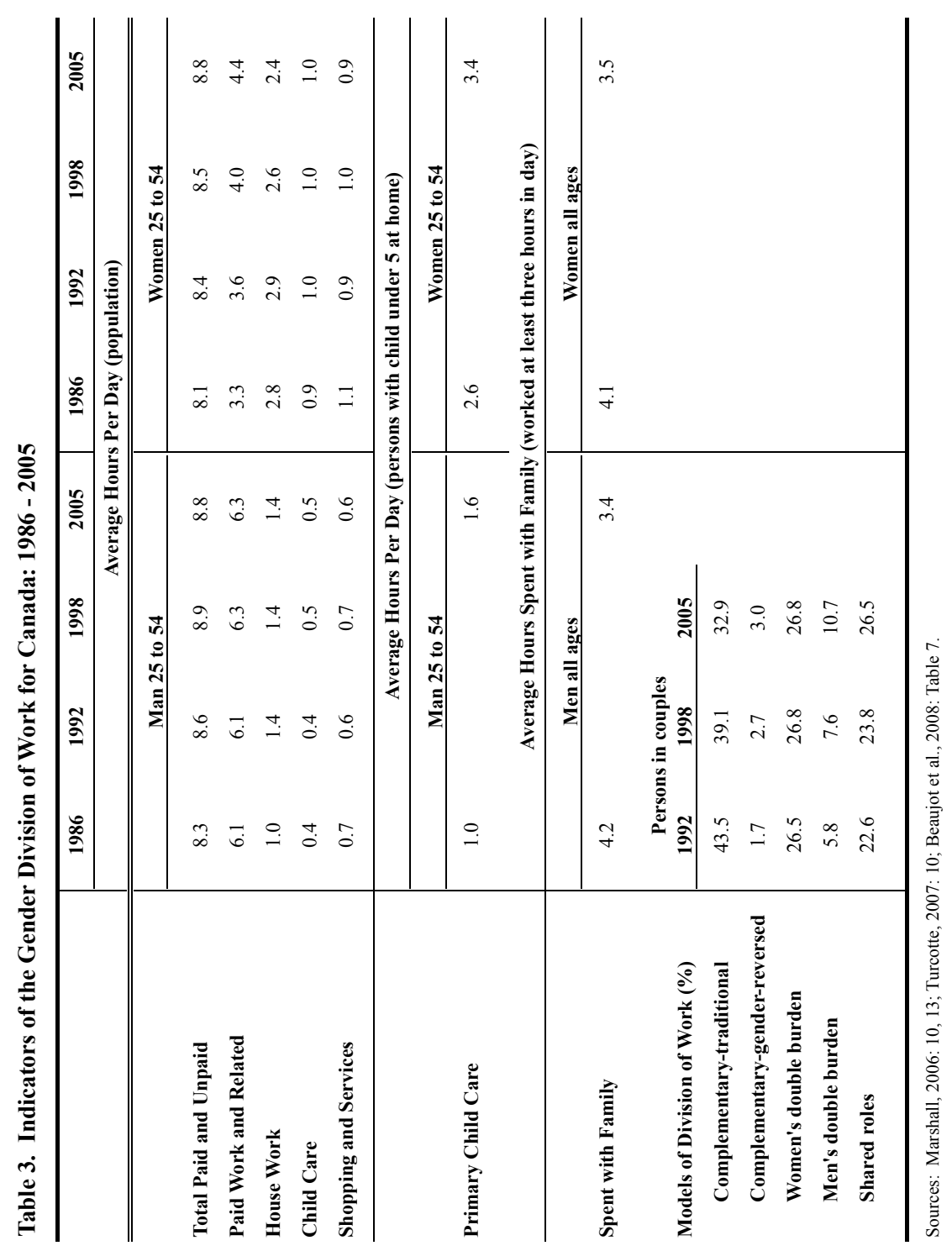

CSP 2010, 37.3-4: 411-443 424 
division of infant parenting encourage career-oriented educated women to have a second child (Esping-Andersen et al. 2007). In Denmark, this equal division of infant parenting is found to be as important as motherfriendly policies.

Comparative analyses also suggest that the relationship between fertility and women's labour market participation is dependant on the specific institutions of given welfare states (Baizan 2007). In particular, the negative effects of women's employment on childbearing in Italy, Spain, and the United Kingdom, contrast with the positive effect of having a job in Denmark. Employment status has positive effects in Scandinavian countries, while in other countries women with low incomes have a higher probability of childbearing.

\section{Intended Childbearing by Marital Status, Family Structure and Employment Status}

If childbearing is a question of preferences and constraints, intended fertility becomes a useful indicator at both the macro and micro levels. Hagewen and Morgan (2005) propose, at least for the United States, that intended fertility is related to fertility trends. In looking at the fertility trend in Quebec over the previous century, Lapierre-Adamcyk and Lussier (2003) use the title: "De la forte fécondité à la fécondité désirée." Following Bongaarts (2002), it is possible to decompose the departure of actual from intended fertility through factors that reduce childbearing from that intended (e.g. subfecundity, competition with other life goals) and factors that increase childbearing beyond that intended (e.g. unwanted fertility).

In the 2006 Canadian General Social Survey, people who indicated that they did not intend to have another child were asked "Why they did not intend to have another child." The main reasons given were that they had reached their ideal family size (some specified that they had been voluntarily sterilized), or age/health reasons (Keown 2009).

Qualitative studies indicate that there are persistent rationales for having children. Respondents to surveys in London, Ontario, and the surrounding area in 1989-90 and 2000-01 have spoken about having children as "the natural thing to do" and they refer to the importance of replacing successive generations (Beaujot 2000: 248-250). In a survey taken in Tunisia in the early 1980s, we asked "Why do people have children?" The answers came fairly readily: people have children for support in old age, and because "children are the joy of life." When we have since asked this of Canadian respondents, the answers are not so 
readily available, but in some ways one gets to the same ideas: people have children because it is enjoyable to interact with children, and to have someone who will be close to you for your whole life. These rationales might be translated into questions of happiness and avoiding loneliness (Billari 2008; Gierveld 2008). That is, the "value of children" can probably be translated into the concepts of happiness and loneliness. Morgan (2003) proposes that besides biological predispositions and investing in the next generation, having children brings connectedness and meaning to life.

For the population aged 20-44 in the 2006 General Social Survey on Families, the total intended fertility is 2.01 for women and 1.95 for men. Total intended fertility declines with age over the childbearing years, from 2.23 for women and 2.17 for men at ages 20-24, to 1.81 for women and 1.83 for men at ages 40-44 (Table 4). Marital status is the main characteristic that shows significant variation in intended births. At ages $30-44$, both current fertility and total intended fertility are highest for married and formerly married, followed by cohabiting and single.

In their study of intended childbearing for women in marital or cohabiting unions, Edmonston and his colleagues (2008a) find remarkably little variation in average intended births over various segments of the population, and over the four General Social Surveys on families from 1990 to 2006. On marital status and family considerations, intentions were lower for cohabiting than married, for those who had experienced more cohabiting unions or more total unions. Averages were somewhat lower for women who were in the labour force or who had more education, while it was higher for women who were more religious, had more social ties and a stronger sense of belonging. In a separate study of married or cohabiting women who intend to remain childless, Edmonston et al. (2008b) find that the average rates are low, in the range of 7 to 8 percent. Except for age group 40-44 where it is $13.9 \%$ in 2006 , the rates within age groups have typically declined over the period since 1990 , for the married or cohabiting population.

For women aged 35-44, and for men aged 25-44, the presence of step-children tends to depress additional intended births (Table 5). For instance, total intended births are 0.4 to 0.5 fewer for persons aged $40-44$ who have step-children. This corresponds to the observations of a small qualitative survey that found that the children of one's spouse would sometimes provide a substitute for persons who had zero or one biological children (Beaujot and Bélanger 2001). 
Low Fertility in Canada:

The Nordic Model in Quebec and the U.S. Model in Alberta

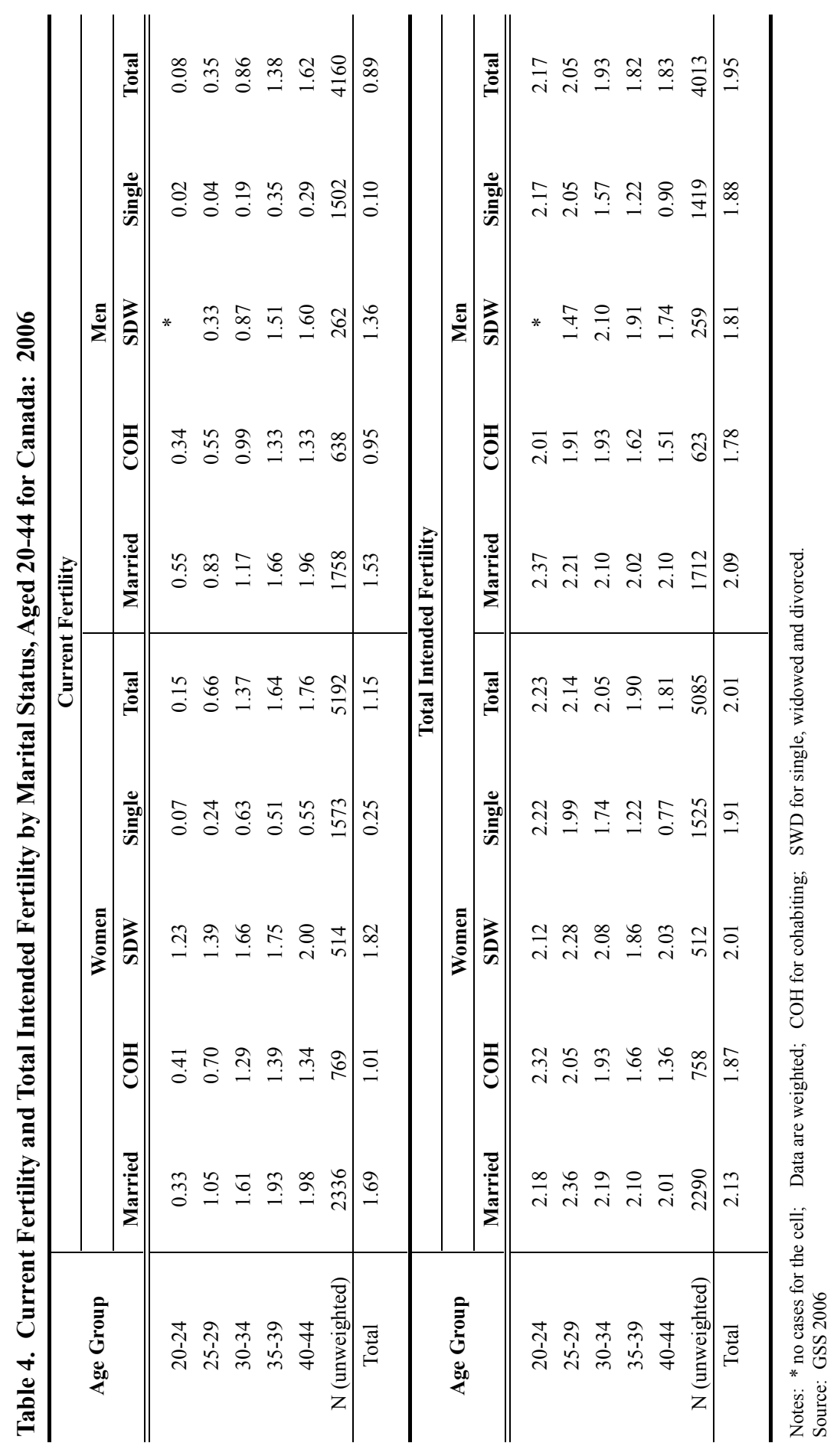

CSP 2010, 37.3-4: 411-443

427 


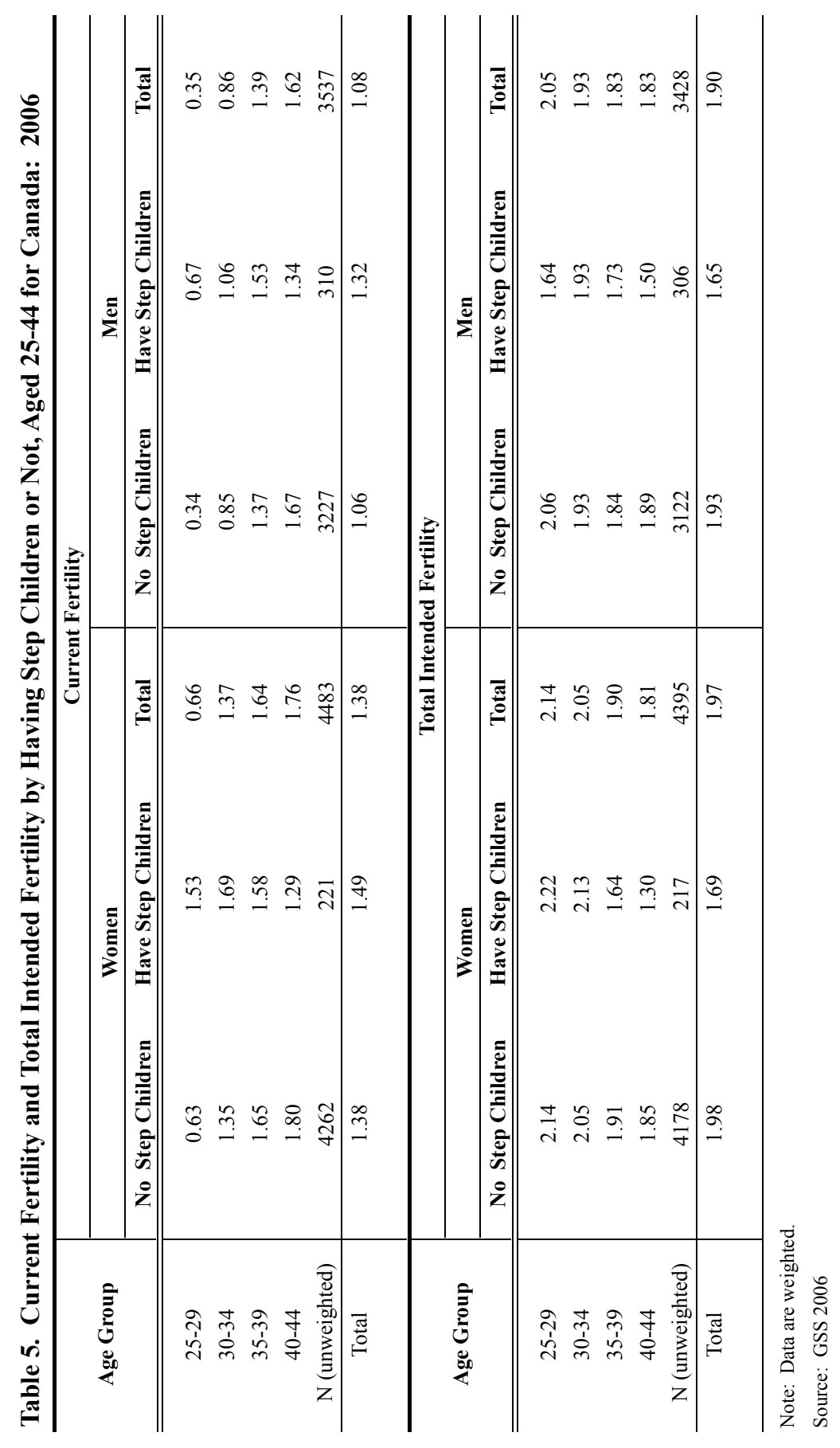

CSP 2010, 37.3-4: $411-443 \quad 428$ 
Low Fertility in Canada:

The Nordic Model in Quebec and the U.S. Model in Alberta

Thus it would appear that later entry into unions, more instability in unions, and more complex family structures are reducing fertility compared to that intended at the onset of childbearing ages. For instance, at ages 40-44, total intended births, which is rather similar to current fertility, is 0.77 and 0.90 for single women and men respectively, while it is 1.36 and 1.51 for those cohabiting, 1.30 and 1.50 for those who have step children, and 2.01 and 2.10 for persons who were married at the time of the survey.

With later entry into relationships, and more separations, more unstable relationships, there is a lower proportion of the population, especially at ages 20-35, who are in relationships that they consider sufficiently stable to have children. The Gender and Generation Surveys from France, Germany and Russia indicate lower progression to a second child for women who have no partner, or when their partner is not employed (Kreyenfeld 2008). Besides, the notion of having a child to stabilize a relationship has been largely excluded.

The characteristics related to work are of lesser importance to differences in intended fertility, probably because there are two models operating. In one model, it is women with limited labour market attachment who have more children. In the two-income model, women have children once they are secure in their work status. Hakim (2003) has further proposed that one could classify women as family-centered, work-centered or balanced. The Family General Social Survey does not have a measure of family vs work orientation, but there is a measure of work orientation through the question on the desire to work more hours for more pay, fewer hours for less pay or the same hours for the same pay. This measure, along with the current work status in terms of fulltime or part-time hours, was used to create a measure of work orientation (Table 6). At ages 35-44, for both women and men, the current and intended fertility tend to be highest for those with intermediate work orientation, while fertility is lowest for those with low work orientation. It may be that intermediate work orientation allows more space for children, while a low work orientation limits the economic basis for childbearing.

\section{The Changing Policy Context}

Gauthier (2008) has theorized that policies would make a difference if they help overcome some of the direct costs of children, but these direct costs are not the only element; equally important would be child care, housing availability, flexible hours of work and the availability of parttime work. She further proposes that policies reducing gender inequality 
Table 6

Current Fertility and Total Intended Fertility by Work-family Balance, Women Aged 35-44 for Canada: 2006

\begin{tabular}{|c|c|c|c|c|}
\hline \multirow{2}{*}{ Variables } & \multicolumn{2}{|c|}{ Current Fertility } & \multicolumn{2}{|c|}{ Total Intended Fertility } \\
\hline & 35-39 & $40-44$ & 35-39 & $40-44$ \\
\hline n (unweighted) & 1180 & 1251 & 1180 & 1251 \\
\hline Total & 1.64 & 1.76 & 1.90 & 1.81 \\
\hline \multicolumn{5}{|l|}{ A. Have Child before 25 or Not } \\
\hline 1. no child & 0.00 & 0.00 & 0.75 & 0.18 \\
\hline 2. have child before 25 & 2.15 & 2.18 & 2.24 & 2.20 \\
\hline 3. have child after 25 & 1.97 & 2.25 & 2.12 & 2.25 \\
\hline 4. child with unknown age at birth & 2.00 & 2.06 & 2.17 & 2.12 \\
\hline \multicolumn{5}{|l|}{ B. Job Interruption or Not } \\
\hline \multicolumn{5}{|l|}{ 1. job interruption of } \\
\hline 12 months or more & 1.59 & 1.67 & 1.92 & 1.70 \\
\hline 2. job interruption of & & & & \\
\hline less than 12 months & 1.67 & 1.80 & 1.89 & 1.87 \\
\hline 3. stopped working & 1.72 & 1.75 & 1.99 & 1.80 \\
\hline 4. never worked & 1.85 & 1.81 & 1.97 & 1.84 \\
\hline 5. worked with no interruption & 1.58 & 1.79 & 1.85 & 1.86 \\
\hline \multicolumn{5}{|l|}{ C. Work-family Balance } \\
\hline 1. work centered & 1.13 & 1.46 & 1.53 & 1.54 \\
\hline 2. balance type 1 & 2.00 & 2.10 & 2.13 & 2.15 \\
\hline 3. balance type 2 & 1.10 & 1.19 & 1.54 & 1.26 \\
\hline 4. family centered & 2.23 & 2.22 & 2.32 & 2.22 \\
\hline
\end{tabular}

Notes: Unweighted $\mathrm{n}$ is given for the first panel. The sample size for other panels are reduced by 22 cases. work centered: panel A catogories $1 \& 3$ AND panel B categories $2 \& 5$.

balance type 1: panel A categories $2 \& 4$ AND panel B categories $2 \& 5$.

balance type 2: panel A categories $1 \& 3$ AND panel B categories $1,3 \& 4$.

family centered: panel A categories $2 \& 4$ AND panel B categories $1,3 \& 4$.

Source: GSS 2006 
in households would be important. What may matter most is not individual policies, but the package of policies, paying attention to the heterogeneity in the population (Gauthier and Philipov 2008).

While Canada's track record is far from that of Nordic countries or France, the movement is in the right direction, with more policy support for families in Quebec than in the rest of Canada. For Canada as a whole, the Child Tax Benefit has replaced family allowance and tax deductions for dependent children, allowing for more benefits to low income families. When this change was made in 1993, the change was revenue neutral, but the program has since been augmented by more than the cost of living. The maximum benefits per child were increased by $65 \%$ between 1993 and 2009, to reach $\$ 3,416$. The payments are reduced for incomes above $\$ 21,287$ and they reach zero at family income of $\$ 95,400$ for families with one or two children, and at $\$ 127,700$ for larger families. It is estimated that nine out of ten families with children receive some benefit (Battle 2009).

Since 1996, there is also a family supplement to Employment Insurance for persons with net family income up to $\$ 25,921$ (in 2009 dollars) for families receiving Child Tax Benefits. This increases the replacement rate of Employment Insurance to as much as $80 \%$ of insurable earnings. In 2006, 7.7 percent of Employment Insurance claimants received a family supplement.

In 2007, a Working Income Tax Benefit, was added to tax benefits (Battle 2009). For single parents and couples, the maximum benefit in 2009 was $\$ 1,680$, paid at family incomes between $\$ 9,720$ and $\$ 14,500$, with reductions to zero at incomes above $\$ 25,700$. Specific provinces have added to the Working Income Tax Benefit.

The changes in the administration of welfare have promoted education and work rather than welfare for persons who are capable of working. This has included the subsidy of child care while people are upgrading their education or working at low incomes. These changes, along with the Child Tax Benefit, the Working Income Tax Benefit and the family supplement to Employment Insurance, have provided additional income to working parents at low income thus facilitating the transition from welfare to work. It would appear that these provisions, along with women's increased levels of education, are partly responsible for the increased employment rates of lone mothers, and the reduced proportions who have low income status (Myles et al. 2007).

Maternity leave was first instituted as part of Unemployment Insurance in 1971. Mothers with the minimum weeks of insurable earnings could claim up to 15 weeks of benefits. As with other 
Unemployment Insurance benefits, there was a two week waiting period and the benefits used the same replacement rate as regular unemployment insurance. In 1990, 10 weeks of parental leave were added to the 15 weeks of maternity leave, but if both parents took leaves they each had a two week waiting period. In 2001, the parental leave was expanded from 10 weeks to 35 weeks, and there was only one waiting period even if the parental leave was shared. Now called Employment Insurance, the replacement rate is $55 \%$ up to a maximum income of $\$ 42,300$ (that is, a maximum payment of $\$ 447$ per week in 2009).

As of 2006, Quebec is administering its own parental leave program, which also covers the self employed and does not include a minimum previous weeks of work (Bureau de l'actuaire en chef, 2008). The Quebec program offers two options. In the "basic plan" there are 18 weeks of maternity leave (70\% replacement rate), plus 5 weeks of paternity leave ( $70 \%$ replacement) and 32 weeks of parental leave (7 weeks at $70 \%$ and rest at $55 \%$ ). In the alternate plan, there are 15 weeks of maternity leave, 3 weeks of paternal leave and 25 weeks of parental leave (all at $75 \%$ replacement rate).

The take up rate for mothers has increased from 58 percent in 2000 to $63 \%$ in 2003-06 (Marshall 2008). The take up rate for fathers increased from 3 percent in 2000 to 23 percent in 2006. This take up rate for fathers in 2006 is very different between Quebec (56\%) and the rest of Canada (11\%).

Turning to child care, there is first the tax deductions for child care expenses. In 2006, the maximum child care expenses that could be claimed as tax deductions was $\$ 7,000$ per eligible child, with an average of about $\$ 3000$ worth of child care expenses for tax filers making a claim. In 2006, a Universal Child Care Benefit of $\$ 1200$ per child under six was added.

The total allocations to child care by provinces, in 2007 dollars, has increased from $\$ 998$ million to $\$ 3,087$ million between 1992 and $2007 / 08$, or a real increase of three-fold (Childcare Resource and Research Unit 2009). This includes the provincial subsidies for building child care centers, operating costs, and subsidies to parents. In Quebec, there was a significant change after 1998, when funds previously used as direct payments to parents were transferred into subsidized child care. For the rest of Canada, the change between 1992 and 2007/08 is a 70 percent increase. Nonetheless, the OECD (2005) report on Canada urges increased funding for childcare as an important priority (see also Daly 2007).

In comparison to other OECD countries, Canadian parental leaves are intermediate, but levels of cash support for families and child care provisions are low (Gauthier and Philopov 2008: 8-11). Nonetheless, 
Low Fertility in Canada:

The Nordic Model in Quebec and the U.S. Model in Alberta

Canada has made some progress in the variety of structures IMDWQHCHMR be in place for prospective parents to feel that they have WXSSRUWRRP the $\square$ society $\square$ in $\square$ overcoming $\square$ some $\square$ of $\square$ the $\square$ costs $\square$ and $\square$ barriers: [Gा transfers, parental leave, \child care $\square$ and $\square$ work-life balance features. \,Q comparison to other OECD countries, पCanada's fertility Lin [2005 \was below what one would expect from the level of women's labour force participation (Thévenon 2008). In this comparison, Canada is placed among countries where financial aid to families is focused on families with low income.

\section{Conclusion}

Among the factors that are responsible for low fertility, the risks experienced by young people, and women in particular, are particularly relevant (McDonald 2006). These risks are partly responsible for the delay in family formation. In that context, it is noteworthy that fertility is rising most in Alberta and Quebec, that is in provinces where young families have had the security of either good job opportunities or supportive social policy.

Given the heterogeneity across families, variety in policy supports is also useful, and progress has been made in this direction. While parental leave has a low replacement rate for those who do not have access to top-up from their employer, its extension to 50 weeks has been an important change. The benefits through Child Tax Benefits is focused on low income families, but around 90 percent of families receive some benefits. For richer families, the Child Tax Benefit is low, but they can take more advantage of the tax deductions for child care expenses. The progress in child care has been slow, but the total expenditures have nonetheless increased, especially for the benefit of lone parent and other low income families. Given the diversity in models of family and work, the Universal Child Care Benefit has the advantage of especially supporting families that are less interested in formal child care. In Quebec, the subsidized child care has also benefited dual-income families.

On the gender side, women's progress in the public sphere has been especially noteworthy, including higher participation in postsecondary education than men (Andres and Adamuti-Trache 2007), and relatively high levels of labour force participation in comparison to other OECD countries (Thévenon 2008). The progress in the private sphere is slower, but men's participation in housework and child care is increasing, as is their uptake in parental leave. 
We are probably safe to say that young people have three competing life course priorities: to live in a durable relationship, to have satisfying secure employment, and to have children (Lapierre-Adamcyk 1990). In small samples taken in classes on the Sociology of Family and Work, some 90 percent place durable relationships and secure employment as "very important" or "important." With regard to having children, the numbers who respond "very important" or "important" is closer to 75 percent. Nonetheless, 90 percent expect to have children. For some 10 to 15 percent, it would seem that the childbearing goals would be those most likely sacrificed if life does not go according to plan.

A number of young people are remaining longer in education and are postponing the transition to adulthood. Family formation is particularly low for persons who are participating in education, and the extension of education is a frequent alternative for young people who are facing an uncertain labour market. It is difficult to determine the extent to which these hesitations, and more generally, the delays in family formation, are questions of life style, or a means of handling risks. If they are life style questions, the economic conditions and the policy context will have little consequence on childbearing. However, the economic downturn as of 2008 is posing additional risks. It was thought that the retirement of the baby boom would finally bring better opportunities for young persons, but this large cohort is now delaying its retirement rather than leaving room for the younger generations.

\section{Acknowledgements}

Paper presented in International Perspectives on Fertility, meetings of the Population Association of America, Detroit, 30 April - 2 May, 2009. The authors wish to acknowledge funding from Social Science and Humanities Research Council of Canada. Responsibility for any errors restVwith the authors. 


\section{References}

Andres, L. and M. Adamuti-Trache. 2007. You've come a long way, baby? Persistent gender inequality in university enrolment and completion in Canada, 1979-2004. Canadian Public Policy 33(1): 93-116.

Baizan, P. 2007. The impact of labour market status on second and higher-order births, in Family Formation and Family Dilemmas in Contemporary Europe, edited by G. Esping-Andersen. Bilbao: Fundacion BBVA $\square$ pp. 93-127

Battle, K. 2009. Beneath the Budget of 2009: Taxes and Benefits. Ottawa: Caledon Institute of Social Policy.

Beaujot, R. 2000. Earning and Caring in Canadian Families. Peterborough: Broadview.

Beaujot, R. 2006. Delayed life transitions: trends and implications, in Canada's Changing Families: Implications for Individuals and Society, edited by K. McQuillan and Z. Ravanera. Toronto: University of Toronto Press, pp. 105-132

Beaujot, R. 2007. Gender models for family and work $\square$ in Exploring Gender in Canada: A Multi-dimensional Approach, edited by B. Matthews and L. Beaman. Toronto: Pearson/Prentice-Hall, pp. 215-219.

Beaujot, R. and A. Bélanger. 2001. Perspectives on below replacement fertility in Canada. University of Western Ontario, Population Studies Centre: Discussion Paper 2001-06.

Beaujot, R. and D. Kerr. 2004. Population Change in Canada. Toronto: Oxford.

Beaujot, R., K. McQuillan and Z. Ravanera. 2007. Population change in Canada to 2017 and beyond: the challenges of policy adaptation. Horizons 9(4): 3-12. 
Beaujot, R. and A. Muhammad. 2006. Transformed families and the basis for childbearing, in Canada's Changing Families: Implications for Individuals and Society, edited by K. McQuillan and Z. Ravanera. Toronto: University of Toronto Press, pp. 15-48[

Beaujot, R., Z. Ravanera and J. Liu. 2009. Models of earning and caring: Trends, determinants and implications. University of Western Ontario, Population Studies Centre Discussion Paper 2009-01.

Bélanger, A. and G. Ouellet. 2002. A comparative study of recent trends in Canadian and American fertility, 1980-1999. Report on the demographic Situation in Canada 2001. Ottawa: Statistics Canada Cat. No. 91-209-XPE.

Bernhardt, E. 2005. No, we should not worry about the future of Europe's population. Paper presented at European Population Day Debate, Congress of the International Union for the Scientific Study of Population, Tours, France (July 18-23).

Billari, F. 2008. The happiness commonality: Fertility decisions in low fertility settings. Paper presented at Conference on How Generations and Gender Shape Demographic Change: Toward Policies Based on Better Knowledge, Geneva: UNECE (May 14-16).

Bingoly-Liworo, G. 2007. La constitution de la descendance au Canada: Le rôle de l'allongement des études, du premier emploi et des conditions d'emploi. PhD thesis, Université de Montréal.

Bingoly-Liworo, G. and E. Lapierre-Adamcyk. 2006.

Devenir parent au Canada: L'effet de l'allongement des etudes. Cahiers québécois de démographie 35(2): 103-140.

Beaupré, P., P. Turcotte and A. Milan. 2006. Junior comes back home: Trends and predictors of returning to the parental home. Canadian Social Trends 82: 28-34.

Boling, P. 2008. Demography, culture, and policy: 8 nderstanding Japan's low fertility. Population and Development Review 34(2): 307-326. 
Low Fertility in Canada:

The Nordic Model in Quebec and the U.S. Model in Alberta

Bongaarts, J. 2002. The end of the fertility transition in the developed world. Population and Development Review 28: 419-443.

Bureau de l'actuaire en chef. 2008. Rapport sur le portrait de la clientèle du Régime québécois d'assurance parentale 2006. Quebec: Bureau de l'actuaire en chef.

Childcare Resource and Research Unit. 2009. Early childhood care and education in Canada: Provinces and territories 2008. Toronto: Childcare Resource and Research Unit.

Chung, L. 2006. Education and earnings. Perspectives on Labour and Income 7(6). Statistics Canada Cat. 75-001-XIE.

Caldwell, J. 2005. Discussant to Session on The \&auses of / ow ) ertility. Conference of the International Union for the Scientific Study of Population, Tours, France (July 18-23, 2005).

Clark, W. 2007. Delayed transitions of young adults. Canadian Social Trends 84: 14-22.

Coleman, D. 2005. Population prospects and problems in Europe. Genus 61(3-4): 413-464.

Cross, P. 2006. Emerging patterns in the labour market: A reversal from the 1990s. Canadian Economic Observer 19(2): 3.1-3.13.

Daly, K. 2007. Gender inequality, growth and global ageing. Goldman SacKs, Global Economics Paper No 154.

Del Boca, D. and C. Wetzels, (eds). 2007. Social Policies, Labour Markets and Motherhood: A Comparative Analysis of European Countries. Cambridge: Cambridge University Press.

Edmonston, B., S. Lee and Z. Wu. 2008a. Factors associated with fertility intentions in Canada: 1990 to 2006. Paper presented at the HRSDC workshop on Monitoring Canadian Families Over the Lifecourse, Ottawa (September 25, 2008). 
Edmonston, B., S. Lee and Z. Wu. 2008b. Childless

Canadian couples. Paper presented at the meetings of the Population Work and Family Policy Research Collaboration, Gatineau (December 13-14).

Esping-Andersen, G., M. Guell and S. Brodmann. 2007. When mothers work and fathers care: Household fertility decisions in Denmark and Spain, in Family Formation and Family Dilemmas in Contemporary Europe, edited by G. Esping-Andersen. Bilbao: Fundacion BBVA, pp. 129-154.

Foot, D. K. 1998. Boom, Bust \& Echo 2000. Toronto: Macfarlane Walter and Ross.

Gauthier, A. 2008. Some theoretical and methodological comments on the impact of policies on fertility. Vienna Yearbook of Population Research 2008: 25-28.

Gauthier, A. and D. Philipov. 2008. Can policies enhance fertility in Europe? Vienna Yearbook of Population Research 2008: 1-16.

Gauthier, A., T. Smeeding and F. Furstenberg. 2004. Are parents in industrialized countries investing less time in children? Population and Development Review 30 (4): 647-671.

Gauthier, H. 2009. Québec et Ontario: des écarts variables dans les domaines sociaux. Institut de la statistique du Québec: Données sociodémographiques en bref 13(2): 6.

Gierveld, J. 2008. In the age of old age. Paper presented at Conference on How Generations and Gender Shape Demographic Change: Toward 3olicies \%ased on \%etter . nowledge, Genevaロ[8 1 ( \&( (May 14-16).

Gil Alonso, F. 2005. The uneven distribution of family responsibilities among women and men and its link with low fertility: Some evidence for European Union countries from Eurobarometer data. Paper presented at the Conference of the International Union for the Scientific Study of Population, Tours, France (July 18-23). 
Low Fertility in Canada:

The Nordic Model in Quebec and the U.S. Model in Alberta

Goldscheider, F., D. Hogan and P. Turcotte. 2006. The other partner: the changing role of good provider for men's union formation in industrialized countries. Canadian Studies in Population 33(1): 25-48.

Goldstein, J., T. Sobotka and A. Jasilioniene. 2009. The end of 'lowest-low fertility? Population and Development Review 35 (4): 663-699.

Hagewen, K. and S. P. Morgan. 2005. Intended and ideal family size in the United States, 1970-2002. Population and Development Review 31(3): 507-527.

Hakim, C. 2003. A new approach to explaining fertility patterns: Preference theory. Population and Development Review 29(3): 349-374.

Institut de la statistique du Québec. 2008. Le bilan démographique du Québec, Edition 2008. Quebec: ISQ.

Kiernan, K. 2001. Cohabitation in Western Europe: Trends, issues and implications, in Just Living Together: Implications of Cohabitation on Families, Children, and Social Policy, edited by A. Booth and A.C. Crouter. Mahwah, NJ: Erlbaum, pp. 3-31.

Kapsalis, C., R. Morissette and G. Picot. 1999. The returns to education, and the increasing wage gap between younger and older workers. Statistics Canada: Analytical Studies Branch Research Paper Series, Cat. No. 11F0019MIE, No. 131.

Keown, L.-A. 2009. Personal communication.

Kreyenfeld, M. 2008. Realities of parenthood and childbearing. Paper presented at Conference on How Generations and Gender Shape Demographic Change: Toward 3olicies \%ased on \%etter . nowledge, GenevaП8 1 ( \&( (May 14-16).

Lapierre-Adamcyk, E. 1990. Faire face au changement démographique: la nécessaire participation des femmes, in Faire Face au Changement Démographique, edited by R. Beaujot. Ottawa: Royal Society of Canada, pp. 11-12. 
Lapierre-Adamcyk, E. and M. H. Lussier. 2003. De la forte fécondité à la fécondité désirée', in La démographie québécoise : enjeux du XXIe siècle, edited by V. Piché and C. Le Bourdais. Montreal: Presses de l'Université de Montréal, $\mathrm{pp} \square$ 66-109.

Lauster, N. 2008. Stagefright and the performance of fatherhood in the United States. Paper presented at the meetings of the Canadian Population Society, Vancouver (June 4-6, 2008).

Le Bourdais, C. and E. Lapierre-Adamcyk. 2004. Changes in conjugal life in Canada: Is cohabitation progressively replacing marriage? Journal of Marriage and Family 66: 929-942.

Lesthaeghe, R. 1995. The second demographic transition in western countries: An interpretation, in Gender and Family Change in Industrialized Countries, edited by K. O. Mason and A. Jensen, Editors, Oxford: Clarendon Press, pp. 17-62.

Marshall, K. 2006. Converging gender roles. Perspectives on Labour and Income 18(3): 7-19.

Marshall, K. 2008. Fathers' use of paid parental leave.

Perspectives on Labour and Income. Ottawa: Statistics Canada Cat No. 75-001-X.

Martel, L., E. Caron-Malenfant, S. Vézina and A.『Bélanger. 2007. Labour force projections for Canada, 2006-203. Canadian Economic Observer 20(6): 1-17.

McDaniel, S. 2008. The conundrum of demographic aging and policy challenges: \$ comparative case study of Canada, Japan and Korea. Paper presented at the meetings of the Canadian Population Society, Vancouver[\%\&(June 2008).

McDonald, P. 2000. Gender equity in theories of fertility. Population and Development Review 26: 427-439.

McDonald, P. 2006. Low fertility and the state : The efficacy of policy. Population and Development Review 32(3): 485-510.

Morgan, S. P. 2003. Is low fertility a Twenty-First-Century demographic crisis? Demography 40(4): 589-603. 
Morissette, R. 1998. The declining labour market status of young men, in Labour Markets, Social Institutions and the Future of Canada's Children, edited by M. Corak. Ottawa: Statistics Canada, Cat. No. 89-553, pp. 31-50.

Morissette, R. 2008. Earnings in the last decade. Perspectives on Labour and Income 20(1): 57-69

Morissette, R. and A. Johnson. 2005. Are good jobs disappearing in Canada? Statistics Canada: Analytical Studies Branch Research Paper Series, Cat. No. 11F0019MIE, No. 239.

Myles, J., F. Hou $\square$ G. Picot and K. Myers. 2007. Employment and earnings among lone mothers during the 1980s and 1990s. Canadian Public Policy 33(2): 147-172.

Never, G. 2008. Moving toward gender equality. Paper presented at Conference on How Generations and Gender Shape Demographic Change: Toward 3olicies \%ased on \%etter

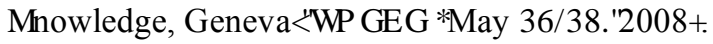

OECD $\square$ 2005. Babies and Bosses: Reconciling Work and Family Life, Vol 4: Canada, Finland, Sweden and the United Kingdom. Geneva: OECD.

Olah, L. 2003. Gendering fertility: Second births in Sweden and Hungary. Population Research and Policy Review 22: 171-200.

Oppenheimer, V. 1998. A theory of marriage timing. American Journal of Sociology 94: 563-591.

Pailhé, A. 2008. Walking the tightrope of career and family. Paper presented at Conference on How Generations and Gender Shape Demographic Change: Toward 3olicies \%ased on \%etter . nowledge, GenevaП18 1 ( \&( (May 14-16).

Pinnelli, A. 2001. Les déterminants de la fécondité en Europe: nouvelles formes de familles, facteurs contextuels et individuals, in Fécondité et nouveaux types de ménages et de formation de la famille en Europe, edited by A. Pinnelli, H. Hoffomann-Nowtny and F. Beat. Strasbourg: Conseil de l'Europe, Etudes démographiques, Vol. 35. 
Purr, A., L. Olah, M. Tazi-Preve and J. Dorbritz. 2009. Men's childbearing desires and views of the male role in Europe at the dawn of the $21^{\text {st }}$ century. Demographic Research: online journal available at demographic-research.org.

Ranson, G. 1998. Education, work and family decision making: Finding the "right time" to have a baby. Canadian Review of Sociology and Anthropology 35(4): 517-533.

Roy, L. and J. Bernier. 2006. La politique familiale, les tendances sociales et la fécondité au Québec: une expérimentation du modèle nordique? Quebec: Ministère de la Famille, des Aînés et de la Condition féminine.

Scoffield, H. 2006. Women in the East join work force, women in West leave in droves. The Globe and Mail, Business Section, 16 June 2006.

Statistics Canada $\square$ 2008. Report on the Demographic Situation in Canada 2005 and 2006. Ottawa: Statistics Canada Cat. No. 91-209-X.

Statistics Canada 2009 . Births 2007. Ottawa: Statistics Canada Cat. No. 84F0210X,

Sunter, D. 2001. Demography and the labour market. Perspectives on Labour and Income 13(1): 28-39.

Sweeney, M. 2002. Two decades of family change: the shifting economic foundations of marriage. American Sociological Review 67: 132-147.

Testa, M. R. and L. Toulemon. 2006. Family formation in France: Individual preferences and subsequent outcomes. Vienna Yearbook of Population Research, 2006: 41-75.

Thévenon, O. 2008. Les politiques familiales des pays développés: des modèles contrastés. Population et Sociétés 448: 1-4.

Turcotte, M. 2007. Time spent with family during a typical workday, 1986 to 2005. Canadian Social Trends 83: 2-11. 
Usalcas, J. 2009. The labour market in 2008. Perspectives on Labour and Income 21(1): 47-52.

Vienna Institute of Demography. 2008. European Demographic Data Sheet 2008. Austria: VID.

Wheeler, M. 2008. Braving the no-go zone: Canada's subreplacement fertility rate. Transition 38(4): 3-8.

Zhang, X. 2009. Earnings of women with and without children. Perspectives on Labour and Income 10(3). Statistics Canada Cat. No. 75-001-XWE. 